\title{
THE EFFECT OF DATE (PHOENIX DACTYLIFERA) JUICE TO INCREASE HAEMOGLOBIN LEVEL OF WHITE RAT (RATTUS NOVERGICUS).
}

Sodiqah, Yani ${ }^{1}$, Abdi, Dian Amelia², Gunawan Sahid $^{3}$, Hafsah,Andi Najmiah ${ }^{4}$

\begin{abstract}
This experiment has conducted on march - April 2015.Background: High Prevalence of anemia in Indonesia, especially defficincy anemia, need several nutrition approaches. Date fruit (Phoenix dactylifera) consist of 23 kinds of amino acyd that make high concentration of protein $(2.3 \%-5.6 \%)$ higher than other fruits. With other substances like Carbohidrat ( total 44\%-88\%), fat (0,2\%-0,4\%), fiber $(6,4 \%-11,5 \%)$, minerals and vitamins, date fruit should be usefull for therapy of anemia. There are several commercial date juice product that should be proved to be a herbal therapy of anemia.Objective: This research aims to know the effect of date (Phoenix dactilafera) juice toward hemoglobin level in white rat blood (Rattus novergicus).Research Method: Twenty four (24) white, male, adult, health and clean rat with weight around 100-200 gr (Rattus novergicus) are divided into four (4) groups. The rats are adapted for seven (7) days, then be measured its hemoglobin degree. Next, they are given with $\mathrm{NaNO}_{2} \quad 10-20$ mg each rat for seven (7) days. The next step is giving date juice $3 \mathrm{cc}$ per oral, given in three groups with three different brands for three days, while the control group is not given date juice. Then, it is done to measure haemoglobin level by using hemoglobin $\mathrm{Hb}$ strip easy touch.Result : The issue of date juice (Phoenix dactilafera) in all tested brands can increase hemoglobin level of white rat (Rattus novergicus) with different percentage. The increasing of hemoglobin level is reached by each brand. The highest rate is taken by Date juice "AJ" $(63,7 \%)$ or 7,0 point, then followed by date juice" $S$ " $(36,8 \%)$ or 4,4 point, and date juice " $T$ " $(8,7 \%)$ or 1,1 point. In the meantime, the control group is around $6,7 \%$ or 0,93 point. Statistically, the increasing of white mice hemoglobin level is significantly just reached by giving Date juice "AJ", justified by one-way ANOVA ( P = 0,0099).Conclusion :The date juice (Phoenix dactilafera) increase the hemoglobin level of white rat (Rattus novergicus)
\end{abstract}

Keywords :date extract (Phoenix dactilafera), white mouse (Rattus novergicus), hemoglobin, anemia.

1.Department of microbiology Medical Faculty of Universitas Muslim Indonesia

2.Department of Dermatology and Venerology Medical Faculty of Universitas Muslim Indonesia

3,4. Student of Medical Faculty of Universitas Muslim Indonesia 


\section{Hasil Penelitian}

Dua puluh empat Tikus putih (Rattus novergicus) dengan berat badan berkisar antara 124 - 162 gram (g). Rerata kadar Hb tikus sebelum perlakuan adalah 17,38 g/dl.

Tabel 5.2 Kadar Hb tikus sebelum pemberian NaNO2 dan sari kurma (g/dl)

\begin{tabular}{cccc}
\hline SUBJEK & Hb & SUBJEK & Hb \\
\hline \hline 1 & 17.5 & 13 & 18 \\
2 & 16.8 & 14 & 19.4 \\
3 & 15.7 & 15 & 18.5 \\
4 & 17.5 & 16 & 21.5 \\
5 & 20.7 & 17 & 14.9 \\
6 & 18.6 & 18 & 15 \\
7 & 16.9 & 19 & 14 \\
8 & 15.5 & 20 & 16.4 \\
9 & 19.4 & 21 & 13.9 \\
10 & 17.7 & 22 & 17.5 \\
11 & 16 & 23 & \\
12 & 19.1 & 24 & \\
\hline & & & \\
\hline & & 217.62 & \\
\hline
\end{tabular}

Tabel 5.2 menunjukkan hasil pengukuran kadar hemoglobin setelah diadaptasikan dan sebelum pemberian $\mathrm{NaNO}_{2}$. Pengukuran menggunakan strip $\mathrm{Hb}$ test "easy touch". Darah diambil dari ekor tikus sebanyak 1-2 tetes, hasil diperoleh dalam 15 detik setelah penetesan pada strip. $\mathrm{NaNO}_{2}$ diberikan per oral setelah dicampurkan dengan aquades, dengan spoit tanpa jarum dan disambung dengan kanula khusus. Dosis $\mathrm{NaNO}_{2} 35 \mathrm{mg} / \mathrm{ml}$ per ekor pada hari pertama menyebabkan kematian 4 ekor tikus. Dilakukan penurunan dosis sampai $20 \mathrm{mg} / \mathrm{ml}$. Sehingga total tikus yang tersisa 16 ekor. Kami mengubah protocol, memulai dengan dosis kecil $5 \mathrm{mg} / \mathrm{ml}$ ditingkatkan hingga $15 \mathrm{mg} / \mathrm{ml}$. Tidak menunggu hingga perlakuan selesai selama 18 hari, melainkan menyeleksi tikus yang 
telah mengalami penurunan kadar $\mathrm{Hb} 4$ - 5 digit dari $\mathrm{Hb}$ awal, langsung dimasukan dalam kelompok perlakuanSehingga kisaran waktu pemberian natrium nitrit adalah $7-18$ hari.

Tabel 5.2 Kadar Hb (g/dl) tikus sesudah pemberian NaNO2

\begin{tabular}{lcccc}
\hline Grup/subjek & $\mathrm{S}$ & $\mathrm{AJ}$ & $\mathrm{T}$ & Kontrol** \\
\hline \hline T1* & 10.8 & 15.3 & 15.6 & 17.1 \\
$\mathrm{~T} 2$ & 12.9 & 10.3 & 13.4 & 14 \\
$\mathrm{~T} 3$ & 13.3 & 9.8 & 15.4 & 9.8 \\
$\mathrm{~T} 4$ & 13.4 & 11.3 & 16.4 & 20.9 \\
Rata-trata & 12.6 & 11.68 & 15.2 & 15.45 \\
\hline
\end{tabular}

*Tikus no $1-4$

** kadar hemoglobin darah g/dl

Dari tabel 5.2 di atas diketahui bahwa rerata kadar $\mathrm{Hb}$ tikus putih setelah pemberian $\mathrm{NaNO}_{2}$ selama 18 hariberkisar antara 11,68 - 15,45 g/dl . Kelompok yang akan diberikan sari kurma $\mathrm{AJ}$ memiliki rata-rata $\mathrm{Hb}$ terendah yaitu 11,68 g/dl sedangkan ratarata $\mathrm{Hb}$ tertinggi adalah grup kontrol, yaitu 15,45. Pakan tikus berupa roti tawar dan air gallon isi ulang. Aktivitas tikus terlihat lamban dan tidak agresif.

Tabel 5.3 kadar Hb tikus sesudah pemberian Sari kurma (g/dl)

\begin{tabular}{lllll}
\hline Grup/sub-jek & S & AJ & T & Kontrol \\
\hline T1* & $18.7^{* *}$ & 20.7 & 14.5 & 18.3 \\
T2 & 15.3 & 17.6 & 19.1 & 14.8 \\
T3 & 15 & 18.9 & 16.9 & 10.9 \\
T4 & 19.1 & 17.6 & 14.7 & 21.5 \\
Rata-rata & 17.025 & 18.7 & 16.3 & 16.375 \\
\hline
\end{tabular}

*Tikus

** kadar hemoglobin darah 
Kisaran rerata kadar $\mathrm{Hb}$ tikus putih sebelum dan setelah pemberian sari kurmadapat dilihat pada diagram berikut:

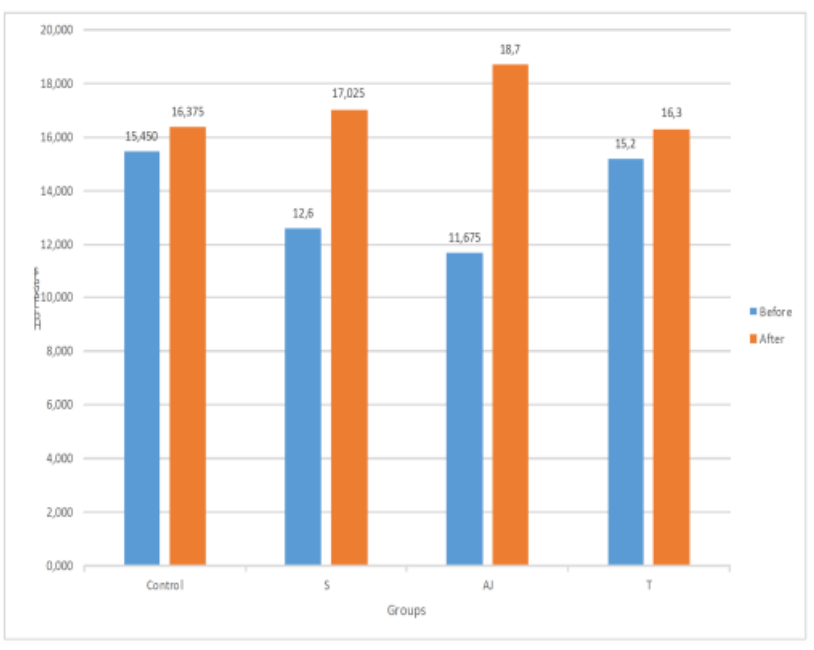

Gambar 5.1 Diagram rata-rata kadar Hb (g/dl) tikus putih sebelum dan sesudah pemberian sari kurma

Dari diagram diatas didapatkan bahwa selisih kadar hemoglobin sesudah dan sebelum pemberian sari kurma. Selisih terkecil diperoleh pada kelompok kontrol $(0,93)$ dengan prosentasi kenaikan sebesar 6,7 \%. Angka selisih yang tidak jauh berbeda terjadi pada kelompok perlakuan dengan sari kurma $\mathrm{T}(1,1)$ dengan prosentasi kenaikan hanya sebesar 8,7\% . Rata-rata selisih tertinggi diperoleh pada kelompok perlakuan dengan sari kurma AJ $(7,0)$ atau $63,7 \%$, disusul kelompok perlakuandengan sari kurma S sebesar 4,4 atau 36,8 \%. Selisih dan presentasi kenaikan kadar $\mathrm{Hb}$ masing-masing kelompok perlakuan dapat dilihat pada tabel berikut.

Tabel 5.4. Selisih kenaikan kadar Hb (g/dl) tikus sebelum dan sesudah perlakuan

$\begin{array}{lllll}\text { Subjek} / H b & \mathrm{~S} & \mathrm{AJ} & \mathrm{T} & \text { Kon-trol }\end{array}$

\begin{tabular}{llrrr}
\hline \hline T1 & 7.9 & 5.4 & -1.1 & 1.2 \\
$\mathrm{~T} 2$ & 2.4 & 7.3 & 5.7 & 0.8 \\
$\mathrm{~T} 3$ & 1.7 & 9.1 & 1.5 & 1.1 \\
$\mathrm{~T} 4$ & 5.7 & 6.3 & -1.7 & 0.6 \\
\hline Rata-rata & 4.425 & 7.025 & 1.1 & 0.925 \\
\hline \hline
\end{tabular}


Tabel 5.5. Prosentasi (\%) kenaikan Hb tikus setelah perlakuan

\begin{tabular}{lllll}
\hline Subjek/Hb & S & AJ & T & Kontrol \\
\hline \hline T1 & 73.14815 & 35.29412 & -7.05128 & 7.017544 \\
\hline \hline T2 & 18.60465 & 70.87379 & 42.53731 & 5.714286 \\
\hline \hline T3 & 12.78195 & 92.85714 & 9.74026 & 11.22449 \\
\hline \hline T4 & 42.53731 & 55.75221 & -10.3659 & 2.870813 \\
\hline \hline Rata-rata & 36.76802 & 63.69431 & 8.715109 & 6.706783 \\
\hline
\end{tabular}

Data yang diperoleh selanjutnya dengan bantuan SPSS diuji dengan one-way ANOVA, hasilnya tertera pada tabel berikut.

Tabel 5.6. Hasil uji one-way ANOVA

One-way analysis of variance

$\mathrm{P}$ value

$P$ value summary

Are means signif. different? $(\mathrm{P}<0.05)$

Yes

Number of groups

$\mathrm{F}$

R square

0.5986

Dengan nilai $\mathrm{P}=0,0099(<0,05)$, uji ini menunjukan bahwa pemberian sari kurma meningkatan kadar hemoglobin tikus putih secara bermakna. 


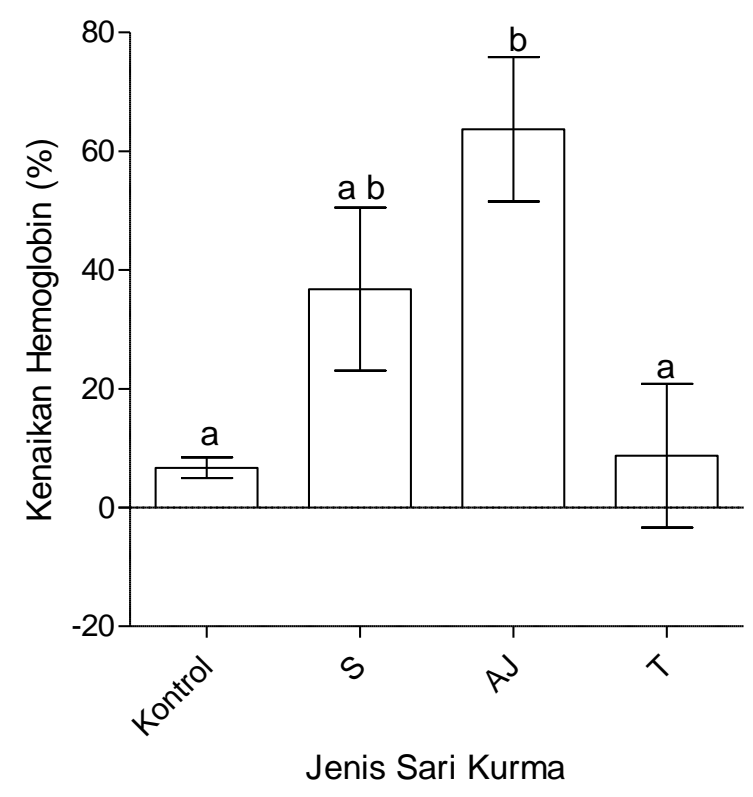

Gambar 5.2. Grafik Prosentasi peningkatan kadar Hb pada setiap kelompok perlakuan

Signifikansi kenaikan kadar hemoglobin tikus putih ditunjukan oleh kelopok perlakuan dengan sari kurma AJ, yang berbeda secara signifikan terhadap kontrol dan kelompok perlakuan dengan sari kurma T. Sementara pada kelompok perlakuan lain dan kontrol tidak terjadi peningkatan $\mathrm{Hb}$ yang segnifikan.

\section{Diskusi}

\section{Penurunankadarhemoglobin}

Untuk mengetahui pengaruh pemberian sari kurma terhadap peningkatan kadar hemoglobin, sebelum diberi perlakuan tikus putih dikondisikan anemia, yaitu dengan memberikan Natrium Nitrit $\left(\mathrm{NaNO}_{2}\right)$ selama 18 hari secara oral (Sediaoetama, Achmad Djaeni. 2006). 
Setelah diberi natrum nitrit, terbukti kadar hemoglobin tikus putih mengalami penurunan. Hal ini seperti pada tabel lampiran, dimana hampir seluruh tikus mengalami penurunan kadar hemoglobin. Rata-rata kadar $\mathrm{Hb}$ tikus sebelum pemberian $\mathrm{NaNO}_{2}$ adalah 17,62 g/dl. Setelah pemberian $\mathrm{NaNO}_{2}$ rata-rata kadar $\mathrm{Hb}$ seluruh subjek turun menjadi $13,73 \mathrm{~g} / \mathrm{dlH}$ asil ini sesuai dengan teori, tentang natrium nitrit yang dapat menurunkan kadar hemoglobin. Natrium Nitrit yang merupakan kontaminan pada air minum, jika tertelan akan memengaruhi proses pengangkutan oksigen oleh hemoglobin. Nitrit akan merubah besi $\mathrm{Fe}^{2+}$ menjadi $\mathrm{Fe}^{3+}$ sehingga hemoglobin tidak akan berfungsi dengan baik. Jika ini terjadi terus menerus akan menyebabkan penurunan kadar hemoglobin hingga anemia.(Yuningsih. 2008)

Hemoglobin merupakan suatu protein yang bertugas membawa oksigen dalam sel darah merah. Hemoglobin mengandung heme yang berkonjugasi dengan polipeptida. Heme adalah suatu derivat porfirin yang mengandung besi. Hemoglobin mengikat $\mathrm{O}_{2}$ untuk membentuk oksihemoglobin, menempel pada $\mathrm{Fe}^{2+}$ dalam heme. Kalau darah terpajan pada aneka macam obat dan agen-agen pengoksidasi lain in vitro atau in vivo, besi ferro $\left(\mathrm{Fe}^{2+}\right)$ dalam molekul tersebut dikonversi menjadi ferri $\left(\mathrm{Fe}^{3+}\right)$ membentuk methemoglobin. Jika telah membentuk methemoglobin, maka tidak bisa lagi berfungsi sebagai alat pengangkut oksigen.( Ganong, W F. 1983)

Pemberian Natrium Nitrit $30 \mathrm{mg} / \mathrm{ml}$ /ekor pada hari pertama menyebabkan 3 ekor tikus mengalami kematian. Dosis ini telah digunakan dalam penelitian yang membuat tikus anemia, sehingga dapat dikatakan aman. Kesalahan mungkin terjadi pada pembuatan larutan Natrium nitrit yang dihomogenisasi secara manual dengan menambahkan bubuk Natrium Nitrit dan aquades. Kematian 4 ekor tikus setelah pemberian solusi yang 
diharapkan menjadi $20 \mathrm{mg} / \mathrm{ml}$ kemungkinan disebabkan oleh hal yang sama. Dosis awal standart adalah $3 \%$ larutan natrium nitrit $10 \mathrm{ml}$, memerlukan waktu kira-kira 12 menit untuk membentuk kira-kira 40\% methemoglobin.(Tintus, Libertus. 2008) Apabila kadar methemoglobin mencapai $20-30 \%$ dari Hb normal. Methemoglobin ini tidak sanggup lagi sebagai pembawa oksigen ke jaringanjaringan, sehingga terjadi kekosongan oksigen dalam darah (hipoksia) dan kemungkinan terjadi defisiensi oksigen dalam jaringan.

Otak adalah jaringan yang paling rentan karena tidak mempunyai cadangan oksigen. Maka terjadinya hipoksia akut yang hebat akan berlanjut dengan kematian (Yuningsih. 2008).

\section{Pengaruh Sari Kurma (Phoenix dactilafera)}

Dari hasil uji di atas memberikan gambaran bahwa sari kurma dapat meningkatkan kadar hemoglobin tikus putih. Pakan tikus saat perlakuan adalah roti tawar yang diasumsikan tidak mengandung mikronutrien yang dibutuhkan dalam pembentukan sel darah merah yang mengandung hemoglobin. Kurma mengandung banyak nutrisi yang cukup lengkap diantaranya mengandung Karbohidrat, Glukosa, Fruktosa, Sukrosa, Magnesium, Kalsium, Fosfor, Folat, Protein, Besi, dan beberapa Vitamin antara lain Vitamin A, Tiamin (B1), Riboflavin (B6), Niasin, dan Vitamin E.Zat besi dan protein yang terkandung dalam kurma berperan sebagai bahan utama pembentuk hemoglobin.( Satuhu, S. 2010)

Zat besi dari sari kurma merupakan zat besi non heme dimana banyak terdapat pada sayuran dan buah-buahan. Zat besi non heme dalam tubuh diserap 1-2\%, namun jika disertai suplementasi Vitamin $\mathrm{C}$ dapat meningkatkan kadar hemoglobin secara bermakna.Zat besi lebih mudah diserap dari usus halus dalam bentuk Ferro. Penyerapan 
ini mempunyai mekanisme autoregulasi yang diatur oleh kadar ferritin yang terdapatdi dalam sel-sel mukosa usus. Pada kondisi Fe yang baik, hanya sekitar $10 \%$ dari Fe yang terdapat di dalam makanan diserap ke dalam mukosa usus, tetapi dalam kondisidefisiensi lebih, banyak Fe dapat diserap untuk menutupi kekurangan zat tersebut.(Sediaoetama, Achmad Djaeni. 2006)

Sebelum diabsorbsi, di dalam lambung besi dibebaskan terlebih dahulu dari ikatan organik, seperti protein. Sebagian besar besi dalam bentuk feri direduksi menjadi bentuk ferro. Hal ini terjadi dalam suasana asam di dalam lambung dengan adanya $\mathrm{HCl}$ dan vitamin $\mathrm{C}$ yang terdapat di dalam makanan. Absorbsi terjadi di bagian atas usus halus (duodenum), sel mukosa yaitu transferin dan ferritin. Tranferin merupakan protein yang disintesis dalam hati, terdapat dalam dua bentuk. Transferin mukosa mengangkut besi dari saluran cerna ke dalam sel mukosa dan memindahkannya ke transferin reseptor yang ada dalam sel mukosa.

Transferin mukosa kemudian kembali ke rongga saluran cerna untuk mengikat besi lain, sedangkan transferin reseptor mengangkut besi melalui darah ke semua jaringan tubuh. (Almatsier, Sunita. 2004)

Kurma (Phoenix dactylifera). merupakan salah satu makanan alami yang memiliki kandungan zat gizi cukup lengkap. Sebutir kurma bisa mengandung hingga 23 macam asam amino sebagai bahan dasar pembentukan protein. Konsentrasi protein kurma $(2.3 \%$ $5.6 \%$ ) jauh lebih tinggi dibanding buah-buahan lain seperti apel, jeruk, pisang dan anggur $(0.3 \%, 0.7 \%, 1.00 \%, 1.00 \%$ protein). Secara garis besar, komposisi kurma terdiri dari karbohidrat ( total 44\%-88\%), lemak $(0,2 \%-0,4 \%)$, protein $2,3 \%-5,6 \%$ ), serat $(6,4 \%$ 11,5\%), mineral dan vitamin (Sulieman, A. M., et all 2012, W. Al-Shahib and R. J. 
Marshall,2003)

Perbedaan prosentasi kenaikan kadar hemoglobin berbeda-beda setiap kelompok, kemungkinan disebabkan oleh jenis kurma yang diolah, mengingat terdapat sekitar lebih dari 2000 varietas buah kurma segar yang diekspor ke berbagai negara (Sulieman, A. M. E., Elhafise, I. A. A., \& Abdelrahim, A. M. 2012). Peningkatan kadar Hb bisa juga disebabkan adanya fortifikasi dengan vitamin dan mineral eksternal pada sari kurma yang beredar di pasaran. Komposisi sari kurma yang tertera pada etiket produk belum bisa menyajikan semua bahan terkandung secara mendetail, sehingga menyulitkan peneliti mencari kadar buah kurma dan zat tambahan lainnya. Semua produk hanya mencantumkan bahan dasar berupa buah kurma dan air. Tidak diketahui kurma yang telah dikeringkan atau buah kurma segar. Tetapi dari warna sari kurma yang coklat tua dan rasa yang hamper sama dengan kurma kering, hampir bisa dipastikan sari kurma yang kami teliti ini berbahan dasar kurma yang dikeringkan atau manisan kurma.

\section{KESIMPULAN}

1. Pemberian sari kurma dapat meningkatkan kadar hemoglobin darah tikus putih

2. Dari tiga merek sari kurma yang diteliti, hanya Sari kurma merk AJ yang dapat meningkatkan kadar hemoglobin darah secara signifikan. 


\section{DAFTAR PUSTAKA}

1. McLean, E., Cogswell, M., Egli, I., Wojdyla, D., \& de Benoist, B. (2009). Worldwide prevalence of anaemia, WHO vitamin and mineral nutrition information system, 1993-2005. Public health nutrition, 12(04), 444-454.

2. Kannammal, N. (2012). Nutritional anaemia. Asian Journal of Nursing Education and Research, 2(1), 37-39. Soegijanto, S. 2004. Penyakit Tropis dan Infeksi di Indonesia. Jilid 2. Surabaya: Airlangga University Press. hlm.1-3.

3. Kusmiati, Sri. 2004. Studi Validitas Dan Reliabilitas Hasil Pemeriksaan Kadar Hemoglobin Dengan Metode Sahli Dan Metode Talqvist Untuk Deteksi Anemia Pada Ibu Hamil Di Puskesmas Wilayah Bojonagara Kota Bandung.Thesis. Yogyakarta: Universitas Gadjahmada.

4. Hipgrave, D. B., Fu, X., Zhou, H., Jin, Y., Wang, X., Chang, S.,Guo, S. (2014). Poor complementary feeding practices and high anaemia prevalence among infants and young children in rural central and western china. European Journal of Clinical Nutrition, $\quad 68(8), \quad 916-24 . \quad$ doi:http://dx.doi.org/10.1038/ejcn.2014.98

5. Kim, J. Y., Shin, S., Han, K., Lee, K. -., Kim, J. -., Choi, Y. S., Ko, B. -. (2014). Relationship between socioeconomic status and anemia prevalence in adolescent girls based on the fourth and fifth korea national health and nutrition examination surveys. European Journal of Clinical Nutrition, 68(2), 253-8. doi:http://dx.doi.org/10.1038/ejen.2013.241

6. Bagni, U. V., Yokoo, E. M., \& Da Veiga, G. V. (2014). Association between nutrient intake and anemia in brazilian adolescents. Annals of Nutrition \& Metabolism, 63(4),323-30.

Doi:http://dx.doi.org/10.1159/000357955

7. Shavelle, R. M., Mackenzie, R., \& Paculdo, D. R. (2012). Anemia and mortality in older persons: Does the type of anemia affect survival? International Journal of Hematology, 95(3), 248-56. doi:http://dx.doi.org/10.1007/s12185-012-1007-z

8. Sebayang, S. K., Pierce, M., Harefa, B., Aditiawarman, A., Apriatni, M. S., Shankar, A. V., ...\& Shankar, A. H. (2013). Maternal anemia modifies the effect of multiple micronutrient supplements on birth weight and infant mortality in Indonesia. The FASEB Journal, 27(1_MeetingAbstracts), 358-7.

9. Profil Sulsel, 2008. Profil Kesehatan Sulawesi Selatan 2008. Dinas Kesehatan Provinsi Sulawesi Selatan. 
10. Brabin, B. J., Hakimi, M., \& Pelletier, D. (2001). An analysis of anemia and pregnancy-related maternal mortality. The Journal of Nutrition, 131(2), 604S-614S; discussion $614 \mathrm{~S}-615 \mathrm{~S}$.

11. Brabin, B. J., Premji, Z., \& Verhoeff, F. (2001). An analysis of anemia and child mortality. The Journal of Nutrition, 131(2), 636S-645S; discussion 646S-648S.

12. Mehansho, H. (2002). Eradication of iron deficiency anemia through food fortification: The role of the private sector. The Journal of Nutrition, 132(4), 831S-3S.

13. Sulieman, A. M. E., Elhafise, I. A. A., \& Abdelrahim, A. M. (2012). Comparative study on five sudanese date (phoenix dactylifera L.) fruit cultivars. Food and Nutrition Sciences, 3(9), 1245-1251.

14. W. Al-Shahib and R. J. Marshall, "The Fruit of the Date Palm: Its Possible Use as the Best Food for the Future," International Journal of Food Science \& Nutrition, Vol. 54, 2003, pp. 247-259.

15. Miller, C. J., Dunn, E. V., \& Hashim, I. B. (2003). The glycaemic index of dates and date/yoghurt mixed meals. are dates 'the candy that grows on trees'? European $\begin{array}{llll}\text { Journal of } \quad \text { Clinical } & \text { Nutrition, } & 57(3), & \end{array}$ 30.doi:http://dx.doi.org/10.1038/sj.ejcn.1601565

16. Satuhu, S. 2010. Kurma Kasiat dan Olahannya. Ed I. Penebar Swadaya. Jakarta.3-5.

17. Rostita. (2010). Khasiat dan Keajaiban Kurma. Bandung: PT Mizan Pustaka. Halaman 24.

18. Alsaed, A. K., Mehyar, G. F., \& Arar, A. (2013). EFFECT OF HARVESTING TIME AND STORAGE TEMPERATURE ON THE DURATION OF BALAH STAGE OF 'BARHI' DATES. Italian Journal of Food Science, 25(3), 345-353.

19. Al-Khuzaim,M.S.(2010). Khasiat Kurma dan Mukjizat Kurma Ajwah. Penerjemah: Abu Umar Basyir. Surakarta: Al-Qowam Semesta. Hal. 11-20.

20. Ganong, W F. 1983. Fisiologi Kedokteran Edisi 10. Alih Bahasa: Adji Dharma.Jakarta: EGC.

21. Sherwood, Lauralee. 2001. Fisiologi Manusia Dari Sel Ke Sistem. Alih Bahasa: Brahm U. Jakarta: EGC. 
22. Guyton, Arthur C dan John E Hall. 1997. Fisiologi Kedokteran. Jakarta: EGC.

23. Penuntun Praktikum Biokimia Biomedik II. Bagian Biokimia Fakultas Kedokteran Universitas Hasanuddin. Makassar. 2011

24. Bakta, I Made dkk. 2009. Buku Ajar Ilmu Penyakit Dalam. Jakarta: Interna Publishing.

25. Sediaoetama, Achmad Djaeni. 2006. Ilmu Gizi Untuk mahasiswa Dan profesi Jilid I. Jakarta: Dian Rakyat.

26. Almatsier, Sunita. 2004. Prinsip Dasar Ilmu Gizi. Jakarta: Gramedia Pustaka.

27. Munawaroh, S. 2009. Pengaruh Ekstrak Kelopak Rosela (Hibiscus sabdariffa L.) Terhadap Peningkatan Jumlah Eritrosit dan Kadar Hemoglobin Dalam Darah Tikus Putih Tikus Putih (Rattus norvegicus) Anemia. [Skripsi]. Malang: Fakultas Sains dan Teknologi Universitas Islam Negeri Maulana Malik Ibrahhim.

28. Srihirun, S., Sriwantana, T., Unchern, S., Kittikool, D., Noulsri, E., Pattanapanyasat, K.,Sibmooh, N. (2012). Platelet inhibition by nitrite is dependent on erythrocytes and deoxygenation. PLoS One, 7(1) doi:http://dx.doi.org/10.1371/journal.pone.0030380

29. Tintus, Libertus. 2008. Dosis Efektif Kombinasi Natrium Tiosulfat Dan Natrium Nitrit Sebagai Antidot Keracunan Sianida Akut Pada Mencit Jantan Galur Swiss. Skripsi. Yogyakarta: Universitas Sanatha Dharma.

30. Yuningsih. 2008. Keracunan Nitrat-Nitrit Pada Hewan Serta Kejadiannya Di Indonesia. Jurnal Penelitian. Bogor: Balai Penelitian Veteriner. Diakses Tanggal 25 April 2009.

31. Muchtadi, Deddy. 1989. Aspek Biokimia. Bogor: Institut Tehnologi Bandung (ITB).

32. Robinson, R. 1979. Taxonomy and Genetics. Dalam : Henry J. B., J. R. Linsey and S.H. Weisborth (Editors). The Laboratory Rat. Volume 1. (Eds). Academic Press. San Diego. Academic Press Inc

33. Oemijati S, Setiabudi R, Budijanto A. 1987. Pedoman Etik Penelitian Kedokteran Indonesia. Jakarta. Penerbit FKUI Hal. 2-22.

34. Nomura T, Tajima Y. 1982. Defined Laboratory Animals, Advances in Pharmacology and Therapeutics II. Oxford. Pergamon Press. 5, 325-327 
35. Sihombing, Marice ,Sulistyowati ,Tuminah,. 2011. Perubahan Nilai Hematologi, Biokimia Darah, Bobot Organ Dan Bobot Badan Tikus Putih Pada Umur Berbeda. Jakarta:Jurnal Veteriner. Diakses Maret 2011.

36. Sulaksono, M Edhie. 2002. Penentuan Nilai Rujukan Parameter Faal Hewan Percobaan Sebagai Model Penyakit Manusia Dan Hewan. Jurnal Penelitian. Jakarta: Litbang Kesehatan. Diakses Tanggal 6 Mei 2009.

37. Suhardjono, D. 1995. Percobaan Hewan Laboratorium. Yogyakarta: Gajah Mada University Press, hal. 207.

38. Sediaoetama, Achmad Djaeni. 2006. Ilmu Gizi Untuk mahasiswa Dan profesi Jilid I. Jakarta: Dian Rakyat. 
